\title{
Correction to: Factors associated with self- rated health in a Norwegian population of older people participating in a preventive home visit program: a cross-sectional study
}

Astrid Fjell ${ }^{1,2^{*}}$, Berit Cronfalk Seiger ${ }^{1,3}$, Monica Hermann ${ }^{4}$, Arvid Rongve ${ }^{5,6}$, Jörg Aßmus ${ }^{7}$, Lars Kvinge ${ }^{4}$, Åke Seiger ${ }^{8}$, Knut Skaug ${ }^{9}$ and Anne-Marie Boström ${ }^{1,2,10}$

Correction to: BMC Geriatr 20, 323 (2020)

https://doi.org/10.1186/s12877-020-01733-2

Following publication of the original article [1], the authors identified some errors in one of the authors' names as well as incorrect date in Table 4. Correct author name and Table 4 data should be as per below:

Berit (B. first name) Cronfalk Seiger (last name).

Table 4 data - Hearing - $0.03(0.11,0.18)$ and Life orientation: $-0.18(0.04,0.39)$.

\footnotetext{
Author details

${ }^{1}$ Department of Neurobiology, Care Sciences and Society, Division of Nursing, Karolinska Institutet, Stockholm, Sweden. ${ }^{2}$ Department of Health and Caring Sciences, Western Norway University of Applied Sciences, Bjørnsonsgate 45, 5528 Haugesund, Norway. ${ }^{3}$ Department of Nursing Science, Ersta Sköndal Bräcke University College, Huddinge, Sweden. ${ }^{4}$ Department of health and caring sciences, Western Norway University of Applied Sciences, Stord, Norway. ${ }^{5}$ Department of Research and Innovation, Helse Fonna, Haugesund Hospital, Haugesund, Norway. ${ }^{6}$ Inst. of Clinical Medicine, University of Bergen, Bergen, Norway. ${ }^{7}$ Centre for Clinical Research, Haukeland University Hospital, Bergen, Norway. ${ }^{8}$ Department of Neurobiology, Care Sciences and Society, Division of Clinical geriatrics, Karolinska Institutet, Stockholm, Sweden. ${ }^{9}$ Department of Research and Innovation, Helse Fonna HF, Haugesund, Norway. ${ }^{10}$ Theme Aging, Karolinska University Hospital, Huddinge, Sweden.
}

Published online: 05 June 2021

\section{Reference}

1. Fjell, et al. Factors associated with self-rated health in a Norwegian population of older people participating in a preventive home visit program: a cross-sectional study. BMC Geriatr. 2020;20:323. https://doi.org/1 0.1186/s12877-020-01733-2.

The original article can be found online at https://doi.org/10.1186/s12877020-01733-2.

* Correspondence: astrid.fjell@hvl.no

'Department of Neurobiology, Care Sciences and Society, Division of Nursing, Karolinska Institutet, Stockholm, Sweden

${ }^{2}$ Department of Health and Caring Sciences, Western Norway University of Applied Sciences, Bjørnsonsgate 45, 5528 Haugesund, Norway

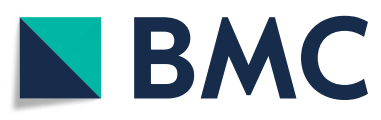

(0 The Author(s). 2021 Open Access This article is licensed under a Creative Commons Attribution 4.0 International License, which permits use, sharing, adaptation, distribution and reproduction in any medium or format, as long as you give appropriate credit to the original author(s) and the source, provide a link to the Creative Commons licence, and indicate if changes were made. The images or other third party material in this article are included in the article's Creative Commons licence, unless indicated otherwise in a credit line to the material. If material is not included in the article's Creative Commons licence and your intended use is not permitted by statutory regulation or exceeds the permitted use, you will need to obtain permission directly from the copyright holder. To view a copy of this licence, visit http://creativecommons.org/licenses/by/4.0/ The Creative Commons Public Domain Dedication waiver (http://creativecommons.org/publicdomain/zero/1.0/) applies to the data made available in this article, unless otherwise stated in a credit line to the data. 